Scientific Research \& Studies Center-Faculty of Science- Zagarig

University - Egypt

Biochemistry Letters

Journal home page:

\title{
Therapeutic effect of Moringa oleifera pods extract and Raspberry ketone against Thioacetamide toxicity in male rats
}

\section{Soha M. Hamdy ${ }^{1}$, Amany M Shaaban ${ }^{1}$, Zakaria A El-khayaht ${ }^{2}$, Abdel Razik Farrag ${ }^{3}$ and Marwa El-Sayed ${ }^{1}$}

1Chemistry Department, Faculty of Science, El Fayoum University, El- Fayoum, Egypt

2Biochemistry Department, National research center, Cairo, Egypt

3Pathology Department, Medical division research, National research center, Cairo, Egypt

\section{A R T I CLE INF O \\ Thioacetamide, M. oleifera}

pods, Rasperry ketone,

oxidative stress,

Histopathology

A B S T R A C T
Background and Aim: Phytochemicals of antioxidant efficiency have either defensive or disease protective properties are widely used worldwide. Aim: This study was performed to assess the therapeutic impact of hydroethanolic extract of Moringa oleifera (M.O) pods and Rasperry ketone (R.K) against the complications accompanied with thioacetamide (TAA) toxicity in male rats. Materials and methods: 88 healthy male rats were separated equally into eleven groups: control group (1); M.O control group (2); R.K control group (3); M.O+R.K control group (4); TAA group (5); M.O protected group (6) RK protected group (7); M.O +R.K protected group (8); Treated M.O (9); Treated RK (10) and Treated M.O+R.K group (11).

Results: The results obtained indicated significant elevation of serum GPT, GOT, AFP, creatinine and urea in TAA model in comparison to all control groups. TAA model also induced significant increase of NO, PON-1 and MDA in both hepatic and renal tissues. However all these parameters are improved in both protected and treated groups as compared to TAA model. The severe damages in both kidney and liver tissues developed by TAA administration resolved by administration of M.O alone or better with both M.O and RK as natural antioxidants. Conclusion: The current research proposed that subjunction of Moringa pods presented more therapeutic effect than Rasperry ketone against the toxicity of TAA in hepatic and renal tissues.

\section{(C) 2017 Publisher All rights reserved.}

\section{INTRODUCTION}

Thioacetamide (TAA) acts as a sulfur source in the production of organic compounds for example elastic chemicals,

healing and treatable agents, mineralogy, insecticides, and drug manufacturing [1]. TAA also used as antifungal agent, a drug 
component, a raw medicine, a textile dye, and a finishing auxiliary [2]. Predominantly, it serves as hepatotoxic and hepato-carcinogenic agent as it causes centrilobular cell death complemented with improved liver enzymes and bilirubin. TAA is widely used as hepatotoxin rats model this result in development of cirrhosis, fibrosis in addition to necrosis of liver ${ }^{[3]}$. To provoke these influences, TAA results in oxidative bio activation into its $S$-oxide (TASO) finally leading to its chemically reactive $\mathrm{TASO}_{2}$ form ${ }^{[4]}$. These metabolites leads to oxidative stress then circulated among some organs as liver, kidney, and bone marrow. Liver is a major organ attacked by reactive oxygen species (ROS) ${ }^{[5]}$.

Antioxidants are usually natural substances that can reduce the effect of the free radicals, convert them from unsafe to safe and lowering the cell injury. Liver cirrhosis and kidney failure can be developed if the inflammation doesn't be stopped [6]. Medicinal phytochemicals have extremely vital position as they used in treatment of numerous diseases, involving hepatic disorders with no toxicity ${ }^{[7]}$.

Moringa oleifera (M.O) is a common vegetable plant in various countries like Egypt, has many therapeutic compounds with beneficial healthcare features, including anti-cancer ${ }^{[8]}$ and antioxidant properties [9]. It is popularly known as drumstick, because it is long and thin, with triangular pods of seeds. It was recently found that $\mathrm{M}$. oleifera seeds were good antioxidants, and can decrease oxidative damage accompanying by cancer ${ }^{[10]}$. Raspberry Ketone (RK) is an aromatic compound present in red raspberry fruits (Rubus idaeus) which is the principal substance responsible for the sweet odor of raspberries and is utilized in a perfume and cosmetics, beverages and food stuffs ${ }^{[11]}$. RK have a double influence of liver protection and body fat drop, and the process included liver inflammation decline, and enhanced antioxidant capability ${ }^{[12]}$.

The purpose of the current research is to assess the effectiveness of both hydroethanolic extract of Moringa oleifera pods and Raspberry ketone opposed to thioacetamide (TAA) toxicity in male rat.

\section{Subjects and methods \\ Chemicals and reagents}

Thioacetamide [TAA] with purity 99\%, and Raspberry ketone (4-(4 Hydroxyphenyl)-2- butanone) $99 \%$ pure were obtained from Sigma chemical company (St Louis, MO, USA). The extract of Moringa oleifera pods was obtained from the Egyptian Scientific Society of Moringa (ESSM), National Research Centre, Egypt.

\section{Preparation of plant extract}

Dry milled pods of Moringa oleifera were put in the Soxhlet thimble with $80 \%$ ethyl alcohol in conical flask, additional refluxed for 18 hours at $80^{\circ}$ for $48 \mathrm{hrs}$. Gathered solvent were cooled at $25^{\circ} \mathrm{C}$ and emptied in a glass plate. The extract was concentrated under vacuum at $40^{\circ} \mathrm{C}$ to produce a semisolid mass, dried in hot air oven below $50^{\circ}$ for 48 hours and stored in desiccators. Suspension of the extract was prepared in distilled water for use.

\section{Animals}

88 health mature male Wistar rats weighting 120-130 g were purchased from the Animal House Colony of the National Research Centre, Egypt. All animals were held in typical circumstances of light, moisture, and warmth with chow and tap water available. This study was conducted according to the guiding principles permitted by the Ethical Committe of Medical Research, National Research Centre, Egypt.

\section{Study plan}

Acclimations for one week, then animals were distributed into eleven groups (8rats/group): Group1 (N. control); animals fed on standard diet. Group2 (M.O control); animals administered oral with M.O extract $(400 \mathrm{mg} / \mathrm{kg})$ daily for 8 weeks. Group3 
(RK control); animals administered oral with RK $(4 \mathrm{mg} / \mathrm{kg})$ daily for 8 weeks. Group 4 (M.O+RK control); animals administered oral with M.O extract $(400 \mathrm{mg} / \mathrm{kg})+\mathrm{RK}(4 \mathrm{mg} / \mathrm{kg})$ daily for 8 weeks. Group 5 (TAA positive control); animals administered with TAA $(200 \mathrm{mg} / \mathrm{kg}) 3$ times $/$ week for 8 weeks. Group 6 (M.O protected); animals administered oral with M.O extract $(400 \mathrm{mg} / \mathrm{kg})$ daily for 14 days before received TAA $(200 \mathrm{mg} / \mathrm{kg})$ 3times/week and continue administered oral with M.O extract $(400 \mathrm{mg} / \mathrm{kg})$ daily for 8 weeks. Group 7 (RK protected); animals administered oral with $\mathrm{RK}(4 \mathrm{mg} / \mathrm{kg})$ daily for 14 days before received TAA $(200 \mathrm{mg} / \mathrm{kg}) 3$ times/week and continue administered oral with $\mathrm{RK}$ $(4 \mathrm{mg} / \mathrm{kg})$ daily for 8 weeks. Group 8 (M.O + R.K protected); animals administered with M.O extract $(400 \mathrm{mg} / \mathrm{kg})+\mathrm{RK}$ $(4 \mathrm{mg} / \mathrm{kg})$ daily for 14 days before received TAA $(200 \mathrm{mg} / \mathrm{kg}) \quad 3$ times/week and continue administered with M.O extract $(400 \mathrm{mg} / \mathrm{kg})+\mathrm{RK}(4 \mathrm{mg} / \mathrm{kg})$ daily for 8 weeks. Group 9 (Treated M.O); animals administered with TAA $(200 \mathrm{mg} / \mathrm{kg})$ 3times/week for 8 weeks then treated with M.O extract $(400 \mathrm{mg} / \mathrm{kg})$ daily for 8 weeks. Group 10 (Treated RK); animals administered with TAA $(200 \mathrm{mg} / \mathrm{kg})$ 3 times/week for 8 weeks then treated with RK $(4 \mathrm{mg} / \mathrm{kg})$ daily for 8 weeks. Group 11(Treated M.O+R.K); animals administered with TAA $(200 \mathrm{mg} / \mathrm{kg}) \quad 3$ times/week for 8 weeks then treated with M.O extract $(400 \mathrm{mg} / \mathrm{kg})+\mathrm{RK}(4 \mathrm{mg} / \mathrm{kg})$ daily for 8 weeks.

When study finished, rats were fasted $12 \mathrm{hrs}$ then anesthetized with ether, and blood was obtained through retroorbital venous plexus. Blood samples collected and centrifuged at $3000 \mathrm{rpm}$ for quarter hour in order to get serum and kept at $-20{ }^{\circ} \mathrm{C}$. Serum obtained was utilized for evaluation of SGPT, SGOT as hepatic markers and AFP as tumor marker, urea and creatinine as renal markers. The liver and kidneys were immediately removed, rinsed with cool physiological saline solution and homogenized, centrifuged and the resulting supernatants were stored at $20^{\circ} \mathrm{C}$ for measuring malonadialdyehyde, paraoxinase, and Nitric oxide by spectrophotometer. Moreover, sections of the liver and kidneys of each group were immediately removed and fixed in $10 \%$ neutral formaldehyde for histological study.

\section{Biochemical study \\ Hepatic enzymes}

SGPT and SGOT enzymes were assessed in accordance with the assays of Gella et al., ${ }^{[13]}$.

\section{Tumor biomarker assay}

Alpha-fetoprotein (AFP) level was detected in serum $(\mathrm{ng} / \mathrm{ml})$ by the method described by Acosta ${ }^{[14]}$, its kits obtained from Diagnostic Products Company (Los Angeles, CA, USA).

\section{Kidney function}

Urea and creatinine were detected in serum by the methods of Fabiny \& Ertingshausen ${ }^{[15]}$ and Tabacco et al., [16] respectively.

\section{Oxidative stress markers}

MDA concentrations were measured in both hepatic and renal tissues by the technique of Ohkawa et al., ${ }^{[17]}$, Paraoxinase-1 (PON1) was performed in both hepatic and renal tissues by the technique of Higashino et al., ${ }^{[18]}$, and Nitric Oxide (NO) was performed in both hepatic and renal tissues by the assay of Montgomery et al., ${ }^{[19]}$.

\section{Histopathological analysis}

The hepatic and renal tissues were removed and put in $10 \%$ buffered formaldehyde, inserted in paraffin wax afterward mounted into blocks and placed at $4^{\circ} \mathrm{C}$. The paraffin blocks were partitioned on the microtome at $6 \mu \mathrm{m}$ thicknesses. The slides were submerged in xylol to remove parafin then immersed in alcohol with concentrations (90-50\%) and stained with Haematoxylin and Eosin ${ }^{[20]}$.

\section{Statistical test}


It was achieved by microsoft excel and SPSS software (version 20). Results were examined by one way analysis of variance (ANOVA) then Post Hoc analysis to determine significant differences among means ${ }^{[21]}$. The results were stated as mean \pm standard deviation (SD). Differences were considered significant at $p \leq 0.05$.

\section{Results}

There were non-significant elevations in SGPT and SGOT activities in the (M.O, R.K, M.O+R.K) control and treated (M.O and M.O+R.K) groups when compared to normal control. High significant elevation in SGPT and SGOT activities were detected in TAA, protected M.O and protected R.K groups as compared to normal control. Meanwhile as the protected and treated groups compared with TAA group, a high significant reduction was observed. By comparing SGPT and SGOT activities in the treated and protected M.O groups with their control (M.O), a non-significant increase was observed in treated group and significant increase observed in protected one. However by comparing SGPT and SGOT activities in the treated and protected R.K groups with R.K control, a significant elevation ( $p$-values $\leq 0.05$ ) was observed in both. While comparing the treated and protected M.O+R.K groups with M.O+R.K control, non-significant increase was detected (Table 1).

A non-significant decline was detected in serum AFP concentrations in the control (M.O, R.K, M.O+R.K) groups, and highly significant elevation in the rest of groups in comparison to normal control. However as the protected and treated groups compared with TAA group, a high significant decrease was observed. Finally, by comparing the treated and protected groups with their controls, a significant increase was observed (Table 1).

There was a high significant elevation in serum urea and creatinine concentrations in the TAA positive control, protected and treated groups (M.O, R.K and M.O+R.K) compared to normal control. Meanwhile, a markedly depletion in serum urea and creatinine concentration was observed as comparing the protected and treated groups with TAA positive control model. Conversely, there was a highly significant elevation in serum urea and creatinine in the treated and protected groups in comparison with their controls (Table 2).

Table (3) has shown highly significant increase in renal tissue MDA and NO levels in the TAA positive control, protected (M.O, R.K and M.O+R.K) groups as compared to normal control. Whereas, by comparing the renal tissue MDA and NO levels in the protected and treated groups with TAA positive control group, a markedly reduction were detected. Again, by comparing the renal tissue MDA and NO levels in the treated and protected groups with their controls, significant increases were detected.

A non-significant decline in renal PON activity in the control (M.O, R.K, M.O+R.K) groups, protected (M.O, R.K) groups and treated M.O+R.K group was detected when compared to normal control. However when comparing renal PON activity in the protected and treated groups with TAA (positive control), a high significant increase was observed. With respect to compare the treated and protected groups with their controls, nonsignificant decrease were observed (Table 3).

Table (4) has shown high significant elevation in hepatic MDA and NO concentrations in TAA and protected (M.O, R.K, M.O+R.K) groups as compared to normal control. However when comparing hepatic MDA and NO levels in the protected and treated groups with TAA (positive control), a high significant decrease was observed in treated M.O+R.K group, while a significant decrease observed with protected M.O, M.O+R.K groups and treated R.K group. By comparing hepatic MDA and NO levels in the treated and protected groups with their controls, 
significant increases were observed in both.

A high significant decrease in hepatic PON activity was detected in TAA group and protected (M.O, R.K, M.O+R.K) groups as compared to normal control. However when comparing hepatic PON activity in the protected and treated groups with TAA (positive control), a high significant increase ( $p$ values $\leq 0.001$ ) was observed in treated M.O+R.K group. Also significant increase observed with treated (M.O, R.K) groups, while non-significant increase was observed in protected (M.O, R.K, M.O+R.K) groups. By comparing hepatic PON activity in the treated and protected groups with their controls significant decreases were observed (Table 4).

\section{Histopathological results of hepatic tissues}

Hepatic sections of control (Fig.1a), M.O control (Fig.1c), R.K control (Fig.1d) and M.O+ R.K control (Fig.1e) groups showed a normal construction of the liver lobule. The central vein (CV) placed at the center of the lobule enveloped by cords of hepatocytes (HC). The hepatocytes shows strongly eosinophilic granulated cytoplasm and round nuclei. Between the strands of hepatocytes the hepatic sinusoids are often seen (HS). In TAA treated group, there were progressive modifications in several hepatocytes, irregular dense fibrotic septa and focal necrosis. The nuclei show different form of injury including; pyknosis, karyohexsis or karyolysis (Fig.1 (b1). On the other hand, disruption of the liver lobules, hydropic deterioration and vacuoles in the hepatocytes are noticed (Fig.1 (b2)

Liver sections of protected M.O group were nearly like normal (Fig.1 f). While, protected R.K group showed congested portal tract associated with inflammatory infiltration (Fig.1 g). In protected M.O+R.K group, microscopic examination of liver sections showed disruption of the hepatic lobules and focal necrosis of the hepatocytes (Fig.1 h). Microscopic examination of liver sections of treated rats given M.O, R.K and M.O+ R.K after TAA showed the hepatic lobules nearly like normal (Fig.1(i, j, k respectively)

\section{Histopathological results of kidney tissues}

Kidney sections of control (Fig.2a), M.O control (Fig.2c), R.K control (Fig.2d) and M.O+ R.K control (Fig.2e) groups showed the normal architecture of the renal corpuscles and renal tubules. Kidney section of TAA-treated rat showed some cellular debris and haemorrhagic areas in the dilated interstitial spaces. The glomeruli showed hypercellularity with wide urinary spaces. On the other hand, the cells of the renal tubules showed many progressive alterations with karyolytic nuclei (Fig.2 b).

Kidney sections of protected M.O and protected M.O+RK groups showed the architecture of the renal corpuscle and renal tubules appeared like normal (F.g. $2 \mathrm{f}$ and $h$ respectively). While protected R.K group showed swelling of the renal corpuscles associated with wide urinary spaces, edema, and inflammatory infiltration in the interstitial space (Fig.2 g). Administration of thioacetamide to rats then given M.O only, R.K only or M.O+ R.K exhibited that the architecture of the renal corpuscles and renal tubules appeared nearly like normal (Fig.2 (i, j, k respectively).

\section{Discussion}

Thioacetamide (TAA) is a sulfur containing, carcinogenic agent ${ }^{[22]}$ and producing hepatic failure [23]. Several reports exhibited that the contact to TAA caused hepatic damage, fibrosis and cirrhosis in experimental rats $[24,25]$. Therefore, it is essential to improve the function of natural antioxidants in organ toxicity inhibition in different researches. M. oleifera was a multipurpose plant that could be used as a medicinal plant possesses antitumor, anti-inflammatory, antiulcer, antihypertensive, antioxidant, 
antidiabetic, hepatoprotective and antimicrobial activities ${ }^{[26]}$. M. oleifera seeds have protective effect on liver, antiinflammatory and anti-fibrotic properties [27]. Also, Raspberry Ketone (R.K) is an aromatic compound present in raspberry fruits; it is promoted as a dietary supplement, as a product to help promote weight loss ${ }^{[28]}$.

The current study showed a nonsignificant elevation in both SGPT and SGOT levels in control (M.O, R.K, M.O+R.K) and treated (M.O+R.K) groups when compared to normal control. This reflects a safe effect on the gastrointestinal tract physiology and/or food assimilation; consequently did not damage the organs physiology. This finding is matched with that of Geleta et al., ${ }^{[29]}$, Waterman et al., ${ }^{[30]}$ and Bibi et al., ${ }^{[31]}$. Our data obtained high significant elevation in SGPT and SGOT activities in TAA group in comparison with normal control, this result is consistent with findings of Al-Hashem et al., ${ }^{[32]}$ who stated that the modifications stimulated by TAA in liver enzymes may be due to the oxidative damages of liver cells. Also, Mustafa et al., ${ }^{[33]}$ found that TAA induced animals showed significant elevation in activities of SGPT and SGOT.

In our results, when comparing the protected and treated groups with TAA (positive control), a significant decrease in SGPT and SGOT were observed. This indicated the hepatoprotective effect of M.O and R.K and both of them against TAA, also our results showed that M.O and R.K and M.O+R.K in the treated groups (administered after TAA) give better results than those of protective groups (M.O and R.K administered before TAA), this result is consistent with findings of Wang et al., ${ }^{[12]}$ who indict the hepatoprotective effect of RK. Also, confirmed with that of Bahr\& Farouk ${ }^{[34]}$.

In the present result a high significant increase was detected in serum AFP in TAA group comparable with normal control this may be due to increase in tumor development. This finding agreed with that of Hessin et al., [35]. Alternatively, treated groups exhibited significant decreases in AFP in compare to TAA. However, MO extract was more effective than RK extract or a mixture of both to improve AFP in TAA gp. These results matched with Hessin et al., ${ }^{[35]}$ who stated that decrease in AFP level after M.O administration may be because of declines in the rate of tumor generation.

With regard to renal function, our research showed a non-significant alteration in serum creatinine and urea concentrations in M.O, R.K and M.O+R.K control groups in comparison with control. Our finding approved the nephroprotective influence of these medicinal plants. However a highly significant elevation was detected in TAA group as compared to normal control group, our study consistent with Begum et al., ${ }^{[36]}$ and Kadir et al. ${ }^{[37]}$ who stated that the high levels of serum urea and creatinine reveal kidney damage. Meanwhile in this study, a high significant decrease in levels of urea and creatinine was detected in the protected and treated groups (M.O, R.K and M.O+R.K) as compared with TAA group this proved the protective effect of M.O and R.K. This study is in agreement with Karthivashan et al. ${ }^{[38]}$.

Conversely, the treated groups in this study showed obvious reversion (more than protected group) of the hepatic and renal markers almost close to that of the control group.

In our study, TAA group induced significant increase of $\mathrm{NO}$ and MDA in liver tissue this finding agrees with that of Mustafa et al., ${ }^{[33]}$. In addition, in RK treated group there was a significant reduction in MDA concentration in comparison with TAA group, our finding matched with that of Wang et al., ${ }^{[12]}$. However, administration of MO in treated groups significantly decreased the levels of MDA and NO in comparison with the TAA group. Karthivashan et al., [38] demonstrated that the existence of flavonoids such as kaempferol, apigenin, 
quercetin, and multiflorin in the MO extract responsible for advancing antioxidant potential. While significant elevation in the level of NO was detected in treated (M.O, R.K, M.O+R.K) groups as compared to TAA gp.

Furthermore, animals groups treated with TAA and M.O recorded a significant improvement in hepatic levels MDA, NO, and PON in compare to the animals group intoxicated with TAA alone; the highest improving potential was recorded with regard animal group treated with M.O in combination with TAA. This finding is confirmed with that of Yassa \& Tohamy ${ }^{[39]}$; Bahr \& Farouk, ${ }^{[34]}$ and Bibi et al., [31]. Our data revealed a high significant decrease in hepatic PON activity was detected in TAA group and protected (M.O, R.K, M.O+R.K) as compared to normal control group. This finding matched with that of Marsillach et al., ${ }^{[40]}$ who stated that with hepatitis or cirrhosis, the concentration of PON-1 in plasma is decreased by $50 \%$ and the decrease is proportional to the degree of tissue injury. Also, in our results a significant decrease was observed in the control (M.O, M.O+R.K) and treated (M.O, R.K) groups against normal control. These results prove the protective action of M.O and R.K against liver tissue damage.

Our study showed that severe histopathological changes in liver tissue following TAA administration that vary from irregular dense fibrotic septa and focal necrosis of the hepatocytes. The nuclei showed different form of injury. These injuries were in the form of pyknosis, karyohexsis or karyolysis. Also, hepatic lobules disruption, hydropic deterioration and vacuoles in the liver cells were detected. This is consistent with AlAttar and Al-Rethea, ${ }^{[41]}$.

The microscopic examinations in the TAA+ M.O, TAA+ R.K and TAA+ M.O+ R.K protected group showed reduced complexity of microscopic modifications in comparison with the TAA group. On the other hand all treated groups
(TAA+ M.O, TAA+ R.K and TAA+ M.O+ R.K) showed improvement of the hepatic lobules looked like normal. It has been observed that the antioxidant and hepatoprotective effect of M. O leaves extract with R.K as it was also confirmed by the histopathological picture of the liver. This find is agreement with Yassa \&Tohamy ${ }^{[39]}$ who reported that hepatic sections of rats treated with Moringa extract only exhibited normal histological construction of the hepatic lobules and central vein compared to normal animals.

In our results the histopathological examination of kidney section of TAAtreated rat showed some cellular debris and haemorrhagic areas in the dilated interstitial spaces. The glomeruli showed hypercellularity with wide urinary spaces. On the other hand, the renal tubules cells showed many degenerative alterations with karyolytic nuclei. This result was confirmed with several studies [42, 37]. Administration of thioacetamide to rats then given M.O only, R.K only or M.O+ R.K exhibited that the architecture of the renal corpuscles and renal tubules appeared more or less like normal. This proves the protective action of these medicinal plants on renal tissue.

In conclusion: Regarding the histopathological and biochemical examination of liver and kidney tissues, it was noticed that the administration of TAA result in severe damage in the tissue which can be resolved by administration of M.O alone or better with both M.O and RK as natural antioxidants. Briefly; this study clearly demonstrated a strong evidence for the treatable action of hydroethanolic extract of M.O pods and aqueous solution of R.K for hepatic and renal tissue damage, and anti-toxic efficiencies of both.

\section{References}

[1] Cinghită, D., Radovan, C., \& Dascălu, D. (2008). Anodic voltammetry of thioacetamide and its amperometric determination in aqueous media. Sensors, 8(8), 4560-4581.

[2] Chen, L. H., Hsu, C. Y., \& Weng, C. F. (2006). Involvement of P53 and $\mathrm{Bax} / \mathrm{Bad}$ 
triggering apoptosis in thioacetamide-induced hepatic epithelial cells. World Journal of Gastroenterology: WJG, 12(32), 5175.

[3] Li, X., Benjamin, I. S., \& Alexander, B. (2002). Reproducible production of thioacetamide-induced macronodular cirrhosis in the rat with no mortality. Journal of hepatology, 36(4), 488-493.

[4] Hajovsky, H., Hu, G., Koen, Y., Sarma, D., Cui, W., Moore, D. S., ... \& Hanzlik, R. P. (2012). Metabolism and toxicity of thioacetamide and thioacetamide S-oxide in rat hepatocytes. Chemical research in toxicology, 25(9), 1955-1963.

[5] Sánchez-Valle, V., C Chavez-Tapia, N., Uribe, M., \& Méndez- Sánchez, N. (2012). Role of oxidative stress and molecular changes in liver fibrosis: a review. Current medicinal chemistry, 19(28), 4850-4860.

[6] Friedman, S. L. (2000). Molecular regulation of hepatic fibrosis, an integrated cellular response to tissue injury. Journal of Biological Chemistry, 275(4), 2247-2250.

[7] Govind, P. (2011). Medicinal plants against liver diseases. IJPR, 2, 115-121.

[8] Abd-Rabou, A. A., Zoheir, K. M., Kishta, M. S., Shalby, A. B., \& Ezzo, M. I. (2016). Nano-micelle of moringa oleifera seed oil triggers mitochondrial cancer cell apoptosis. Asian Pacific journal of cancer prevention: APJCP, 17(11), 4929.

[9] Abdull, R., Ahmad, F., Ibrahim, M. D., \& Kntayya, S. B. (2014). Health benefits of Moringa oleifera. Asian Pacific Journal of Cancer Prevention, 15(20), 8571-8576.

[10] Singh, B. N., Singh, B. R., Singh, R. L., Prakash, D., Dhakarey, R., Upadhyay, G., \& Singh, H. B. (2009). Oxidative DNA damage protective activity, antioxidant and antiquorum sensing potentials of Moringa oleifera. Food and Chemical Toxicology, 47(6), 1109-1116.

[11] Garcia, C. V., Quek, S. Y., Stevenson, R. J., \& Winz, R. A. (2011). Characterization of the bound volatile extract from baby kiwi (Actinidia arguta). Journal of Agricultural and Food chemistry, 59(15), 8358-8365.

[12] Wang, L., Meng, X., \& Zhang, F. (2012). Raspberry ketone protects rats fed high-fat diets against nonalcoholic steatohepatitis. Journal of medicinal food, 15(5), 495-503.

[13] Gella, F. J., Olivella, T., Pastor, M. C., Arenas, J., Moreno, R., Durban, R., \& Gomez, J. A. (1985). A simple procedure for the routine determination of aspartate aminotransferase and alanine aminotransferase with pyridoxal phosphate. Clinica chimica acta, 153(3), 241-247.

[14] Acosta, A. A. (1983). Direct immunoenzymatic determination of AFP in serum or plasma. J Clin immunoassays, 6, 41. [15] Fabiny, D. L., \& Ertingshausen, G. (1971). Automated reaction-rate method for determination of serum creatinine with the CentrifiChem. Clinical chemistry, 17(8), 696700.

[16] Tabacco, A., Meiattini, F., Moda, E., \& Tarli, P. (1979). Simplified enzymic/colorimetric serum urea nitrogen determination. Clinical chemistry, 25(2), 336337.

[17] Ohkawa, H., Ohishi, N., \& Yagi, K. (1979). Assay for lipid peroxides in animal tissues by thiobarbituric acid reaction. Analytical biochemistry, 95(2), 351-358.

[18] Higashino, K., Takahashi, Y., \& Yamamura, Y. (1972). Release of phenyl acetate esterase from liver microsomes by carbon tetrachloride. Clinica Chimica Acta, 41, 313-320.

[19] Montgomery, H. A. C. Dymock,. JF. 1961. Determination of nitric oxide. Analyst, 86, 41-43.

[20] Drury, R. A., Wallington, E. A. C., \& Cameron, S. (1980). Coreleton's Histological technique 4th edition.

[21] Härdle, W., \& Simar, L. (2007). Applied multivariate statistical analysis (Vol. 22007, pp. 1051-8215). Berlin: Springer.

[22] Kizer, D. E., Clouse, J. A., Ringer, D. P., Hanson-Painton, O., Vaz, A. D., Palakodety, R. B., \& Griffin, M. J. (1985). Assessment of rat liver microsomal epoxide hydrolase as a marker of hepatocarcinogenesis. Biochemical pharmacology, 34(10), 1795-1800

[23] Bruck, R., Aeed, H., Shirin, H., Matas, Z., Zaidel, L., Avni, Y., \& Halpern, Z. (1999). The hydroxyl radical scavengers dimethylsulfoxide and dimethylthiourea protect rats against thioacetamide-induced fulminant hepatic failure. Journal of hepatology, 31(1), 27-38.

[24] Ali, S. O., Darwish, H. A., \& Ismail, N. A. (2016). Curcumin, Silybin Phytosome® and $\alpha$-R-Lipoic Acid Mitigate Chronic Hepatitis in Rat by Inhibiting Oxidative Stress and Inflammatory Cytokines Production. Basic \& clinical pharmacology \& toxicology, 118(5), 369-380. 
[25] Luo, M., Dong, L., Li, J., Wang, Y., \& Shang, B. (2015). Protective effects of pentoxifylline on acute liver injury induced by thioacetamide in rats. International journal of clinical and experimental pathology, 8(8), 8990.

[26] Hussein, A. (2017). Comparative Evaluation Of Anticancer Potential Of Moringaoleifera, Ganodermalucidumand Silver Nanoparticles Against Breast And Liver Cancer Cell Lines And Related Pro And Anti Apoptotic Genes Profile. International Journal of Scientific Research and Management, 5(3), 5242-5252.

[27] Hamza, A. A. (2010). Ameliorative effects of Moringa oleifera Lam seed extract on liver fibrosis in rats. Food and Chemical Toxicology, 48(1), 345-355.

[28] Morimoto, C., Satoh, Y., Hara, M., Inoue, S., Tsujita, T., \& Okuda, H. (2005). Antiobese action of raspberry ketone. Life sciences, 77(2), 194-204.

[29] Geleta, B., Makonnen, E., Debella, A., \& Tadele, A. (2016). In vivo antihypertensive and antihyperlipidemic effects of the crude extracts and fractions of Moringa stenopetala (Baker f.) Cufod. leaves in rats. Frontiers in pharmacology, 7, 97.

[30] Waterman, C., Cheng, D. M., RojasSilva, P., Poulev, A., Dreifus, J., Lila, M. A., \& Raskin, I. (2014). Stable, water extractable isothiocyanates from Moringa oleifera leaves attenuate inflammation in vitro. Phytochemistry, 103, 114-122.

[31] Bibi, A., Ullah, F., Mehmood, S., Bibi, K., Khan, S. U., Khattak, A., \& Ullah Khan, R. (2016). Moringa oleifera Lam. leaf extract as bioregulator for improving growth of maize under mercuric chloride stress. Acta Agriculturae Scandinavica, Section B-Soil \& Plant Science, 66(6), 469-475.

[32] Al-Hashem, F., AlHumayed, S., Ellatif, M. A., Amin, S. N., Kamar, S. S., Al-Ani, B., \& Haidara, M. A. (2018). Metformin Protects Against Thioacetamide Induced Liver injury in Rats. International Journal of Morphology, 36(3).

[33] Mustafa, H. N., El Awdan, S. A., \& Hegazy, G. A. (2013). Protective role of antioxidants on thioacetamide-induced acute hepatic encephalopathy: biochemical and ultrastructural study. Tissue and Cell, 45(5), 350-362.
[34] Bahr, H. I., \& Farouk, S. M. (2016). Comparative ameliorative effect of basil oil and Moringa oleifera on lornoxicam-mediated histological and biochemical alterations in albino rat liver. J Vet Sci Tech, 7(2), 1-11.

[35] Hessin, A. F., Hegazy, R. R., Hassan, A. A., Yassin, N. Z., \& Kenawy, S. A. B. (2017). Resveratrol prevents liver fibrosis via two possible pathways: Modulation of alpha fetoprotein transcriptional levels and normalization of protein kinase $\mathrm{C}$ responses. Indian journal of pharmacology, 49(4), 282.

[36] Begum, Q., Noori, S., \& Mahboob, T. (2011). Antioxidant effect of sodium selenite on thioacetamide-induced renal toxicity. Pakistan Journal of Biochemistry and Molecular Biology, 44(1), 21-26.

[37] Kadir, F. A., Kassim, N. M., Abdulla, M. A., \& Yehye, W. A. (2013). Effect of oral administration of ethanolic extract of Vitex negundo on thioacetamide-induced nephrotoxicity in rats. BMC complementary and alternative medicine, 13(1), 294.

[38] Karthivashan, G., Kura, A. U., Arulselvan, P., Isa, N. M., \& Fakurazi, S. (2016). The modulatory effect of Moringa oleifera leaf extract on endogenous antioxidant systems and inflammatory markers in an acetaminophen-induced nephrotoxic mice model. PeerJ, 4, e2127.

[39] Yassa, H. D., \& Tohamy, A. F. (2014). Extract of Moringa oleifera leaves ameliorates streptozotocin-induced Diabetes mellitus in adult rats. Acta Histochemica, 116(5), 844854.

[40] Marsillach, J., Aragonès, G., Mackness, B., Mackness, M., Rull, A., Beltrán-Debón, R., ... \& Camps, J. (2010). Decreased paraoxonase-1 activity is associated with alterations of high-density lipoprotein particles in chronic liver impairment. Lipids in health and disease, 9(1), 46.

[41] Al-Attar, A. M., \& Al-Rethea, H. A. (2017). Chemoprotective effect of omega-3 fatty acids on thioacetamide induced hepatic fibrosis in male rats. Saudi journal of biological sciences, 24(4), 956-965.

[42] Mahmoud, N. H. (2006). Toxic effects of the synthetic food dye brilliant blue on liver, kidney and testes functions in rats. $J$ Egypt Soc Toxicol, 34, 77-84. 
Table1: SGPT \& SGOT activities and AFP levels in the serum of different rat groups

\begin{tabular}{|c|c|c|c|c|}
\hline $\mathrm{C}_{\text {Group }}^{\mathrm{Pa}}$ & eters & $\begin{array}{c}\text { GPT (ALT) } \\
(\mathrm{U} / \mathrm{l})\end{array}$ & $\begin{array}{c}\text { GOT (AST) } \\
(\mathrm{U} / \mathrm{l})\end{array}$ & $\begin{array}{c}\text { AFP } \\
(\mathrm{Pg} / \mathrm{ml})\end{array}$ \\
\hline $\begin{array}{l}\text { Group } 1 \\
\text { N. control }\end{array}$ & $\begin{array}{c}\text { Range } \\
\text { Mean } \pm \text { SD }\end{array}$ & $\begin{array}{l}13.9-27.9 \\
20.03 \pm 5.6\end{array}$ & $\begin{array}{c}41.9-130.9 \\
85.2 \pm 30.9\end{array}$ & $\begin{array}{c}25.1-29.8 \\
27.2 \pm 1.6\end{array}$ \\
\hline $\begin{array}{c}\text { Group } 2 \\
\text { M.O control }\end{array}$ & $\begin{array}{c}\text { Range } \\
\text { Mean } \pm \text { SD } \\
\text { p- value }\end{array}$ & $\begin{array}{c}22.9-26.5 \\
23.6 \pm 1.4 \\
0.453\end{array}$ & $\begin{array}{c}86.2-89.5 \\
87.7 \pm 1.36 \\
0.871\end{array}$ & $\begin{array}{c}23.2-28 \\
25.3 \pm 1.9 \\
0.777\end{array}$ \\
\hline $\begin{array}{l}\text { Group } 3 \\
\text { R.k control }\end{array}$ & $\begin{array}{c}\text { Range } \\
\text { Mean } \pm \text { SD } \\
\text { p- value }\end{array}$ & $\begin{array}{c}7-31.4 \\
21.2 \pm 8.1 \\
0.808\end{array}$ & $\begin{array}{c}59.4-156 \\
98.05 \pm 44.3 \\
0.414 \\
\end{array}$ & $\begin{array}{c}18-30 \\
24.1 \pm 5.03 \\
0.646\end{array}$ \\
\hline $\begin{array}{c}\text { Group } 4 \\
\text { M.O+R.k control }\end{array}$ & $\begin{array}{c}\text { Range } \\
\text { Mean } \pm \text { SD } \\
\text { p- value }\end{array}$ & $\begin{array}{c}22.5-32.2 \\
27.8 \pm 4.6 \\
0.109\end{array}$ & $\begin{array}{c}75.3-79.4 \\
77.96 \pm 1.54 \\
0.644\end{array}$ & $\begin{array}{c}20.2-26.1 \\
23.4 \pm 2.39 \\
\quad 0.575\end{array}$ \\
\hline $\begin{array}{c}\text { Group } 5 \\
\text { TAA control }\end{array}$ & $\begin{array}{c}\text { Range } \\
\text { Mean } \pm \text { SD } \\
\text { p- value }\end{array}$ & $\begin{array}{c}39.5-45 \\
41.67 \pm 1.94 \\
0.000\end{array}$ & $\begin{array}{c}199-221 \\
210.7 \pm 9 \\
0.000\end{array}$ & $\begin{array}{c}130.2-210 \\
172.3 \pm 29.2 \\
0.000\end{array}$ \\
\hline $\begin{array}{c}\text { Group } 6 \\
\text { M.O protected }\end{array}$ & $\begin{array}{c}\text { Range } \\
\text { Mean } \pm \text { SD } \\
\text { p- value } \\
\mathbf{p}^{\text {a }}-\text { value } \\
\mathbf{p}^{\text {b }- \text { value }}\end{array}$ & $\begin{array}{c}33.2-39 \\
36 \pm 2.4 \\
0.001 \\
0.24 \\
0.012\end{array}$ & $\begin{array}{c}115.2-143.2 \\
128.4 \pm 9.5 \\
0.008 \\
0.000 \\
0.012\end{array}$ & $\begin{array}{c}\text { 95.9-130 } \\
113.2 \pm 12.2 \\
0.000 \\
0.000 \\
0.000\end{array}$ \\
\hline $\begin{array}{c}\text { Group } 7 \\
\text { R.k protected }\end{array}$ & $\begin{array}{c}\text { Range } \\
\text { Mean } \pm \text { SD } \\
\text { p- value } \\
\mathbf{p}^{\text {a }} \text { - value } \\
\mathbf{p}^{\mathbf{c}}-\text { value }\end{array}$ & $\begin{array}{c}26.2-49.8 \\
37.7 \pm 10.27 \\
0.000 \\
0.40 \\
0.001\end{array}$ & $\begin{array}{c}137-155.4 \\
146.2 \pm 7.7 \\
0.000 \\
0.000 \\
0.003\end{array}$ & $\begin{array}{c}99.2-136.2 \\
120.7 \pm 13.17 \\
0.000 \\
0.000 \\
0.000\end{array}$ \\
\hline $\begin{array}{c}\text { Group 8 } \\
\text { M.O+R.k protected }\end{array}$ & $\begin{array}{c}\text { Range } \\
\text { Mean } \pm \text { SD } \\
\text { p- value } \\
\text { p }^{\text {a }} \text { - value } \\
\text { p }^{\text {d }} \text { - value }\end{array}$ & $\begin{array}{c}23.5-39.2 \\
31.6 \pm 5.56 \\
0.018 \\
0.04 \\
0.425\end{array}$ & $\begin{array}{c}106-115 \\
110.16 \pm 3.1 \\
0.115 \\
0.000 \\
0.044\end{array}$ & $\begin{array}{c}95-126 \\
106.5 \pm 10.9 \\
0.000 \\
0.000 \\
0.000\end{array}$ \\
\hline $\begin{array}{c}\text { Group } 9 \\
\text { Treated M.O }\end{array}$ & $\begin{array}{c}\text { Range } \\
\text { Mean } \pm \text { SD } \\
\text { p- value } \\
\text { p }^{\mathbf{a}} \text { - value } \\
\mathbf{p}^{\mathbf{b}} \text { - value }\end{array}$ & $\begin{array}{c}15.7-47.1 \\
29.9 \pm 12.9 \\
0.042 \\
0.018 \\
0.189\end{array}$ & $\begin{array}{c}77.3-193.8 \\
115.07 \pm 41.7 \\
0.061 \\
0.000 \\
0.086\end{array}$ & $\begin{array}{c}79-104.6 \\
90.5 \pm 9.6 \\
0.000 \\
0.000 \\
0.000 \\
\end{array}$ \\
\hline $\begin{array}{c}\text { Group } 10 \\
\text { Treated R.k }\end{array}$ & $\begin{array}{c}\text { Range } \\
\text { Mean } \pm \text { SD } \\
\text { p- value } \\
\mathbf{p}^{\text {a }} \text { - value } \\
\mathbf{p}^{\mathbf{c}} \text { - value }\end{array}$ & $\begin{array}{c}16.6-67.6 \\
33.5 \pm 17.5 \\
0.007 \\
0.093 \\
0.012\end{array}$ & $\begin{array}{c}62.8-214.8 \\
159.2 \pm 55.44 \\
0.000 \\
0.002 \\
0.000\end{array}$ & $\begin{array}{c}\text { 88- 102 } \\
95.1 \pm 5.3 \\
0.000 \\
0.000 \\
0.000\end{array}$ \\
\hline $\begin{array}{c}\text { Group } 11 \\
\text { Treated M.O +R.k }\end{array}$ & $\begin{array}{c}\text { Range } \\
\text { Mean } \pm \text { SD } \\
\text { p- value } \\
\text { p }^{\text {a }} \text { - value } \\
\text { p }^{\text {d }- \text { value }}\end{array}$ & $\begin{array}{c}23.2-30.4 \\
26.28 \pm 2.47 \\
0.196 \\
0.002 \\
0.752\end{array}$ & $\begin{array}{c}99.5-120 \\
109.3 \pm 7.02 \\
0.129 \\
0.000 \\
0.05\end{array}$ & $\begin{array}{c}86.2-109 \\
98.7 \pm 7.9 \\
0.000 \\
0.000 \\
0.000 \\
\end{array}$ \\
\hline
\end{tabular}

$p$ value versus normal (negative control)

$p^{(a)}$ value versus TAA (positive control).

$p^{(\mathrm{b})}$ value versus M.O control.

$p^{\text {(c) }}$ value versus R.K control.

$p^{(\mathrm{d})}$ value versus M.O+R.K control.

$p>0.05$ is non-significant, $p \leq 0.05$ is significant 
Table 2: Urea and Creatinine levels in the serum of different rat groups

\begin{tabular}{|c|c|c|c|}
\hline \multicolumn{2}{|c|}{$\mathrm{P}_{\text {Group }}^{\text {Parameters }}$} & $\begin{array}{l}\text { Urea } \\
(\mathrm{mg} / \mathrm{dl})\end{array}$ & $\begin{array}{l}\text { Creatinine } \\
(\mathrm{mg} / \mathrm{dl})\end{array}$ \\
\hline $\begin{array}{l}\text { Group } 1 \\
\text { N. control }\end{array}$ & $\begin{array}{c}\text { Range } \\
\text { Mean } \pm \text { SD }\end{array}$ & $\begin{array}{c}21.7-29 \\
25.9 \pm 3.03\end{array}$ & $\begin{array}{c}0.778-0.9 \\
0.83 \pm 0.056\end{array}$ \\
\hline $\begin{array}{c}\text { Group } 2 \\
\text { M.O control }\end{array}$ & $\begin{array}{c}\text { Range } \\
\text { Mean } \pm \text { SD } \\
\text { p- value }\end{array}$ & $\begin{array}{c}18.3-26.2 \\
21.93 \pm 2.5 \\
0.01\end{array}$ & $\begin{array}{l}0.5-0.89 \\
0.7 \pm 0.17 \\
0.315 \\
\end{array}$ \\
\hline $\begin{array}{c}\text { Group } 3 \\
\text { R.k control }\end{array}$ & $\begin{array}{c}\text { Range } \\
\text { Mean } \pm \text { SD } \\
\text { p- value }\end{array}$ & $\begin{array}{c}26.7-30.2 \\
29.03 \pm 1.36 \\
0.04\end{array}$ & $\begin{array}{c}0.9-1.02 \\
0.95 \pm 0.04 \\
0.372\end{array}$ \\
\hline $\begin{array}{c}\text { Group } 4 \\
\text { M.O+R.k control }\end{array}$ & $\begin{array}{c}\text { Range } \\
\text { Mean } \pm \text { SD } \\
\text { p- value }\end{array}$ & $\begin{array}{c}18.8-28.8 \\
24.2 \pm 4.2 \\
0.28\end{array}$ & $\begin{array}{c}0.51-0.79 \\
0.64 \pm 0.11 \\
0.098\end{array}$ \\
\hline $\begin{array}{c}\text { Group } 5 \\
\text { TAA control }\end{array}$ & $\begin{array}{c}\text { Range } \\
\text { Mean } \pm \text { SD } \\
\text { p- value }\end{array}$ & $\begin{array}{c}57.7-61 \\
59.25 \pm 1.16 \\
0.000\end{array}$ & $\begin{array}{c}2-2.9 \\
2.5 \pm 0.36 \\
0.000\end{array}$ \\
\hline $\begin{array}{c}\text { Group } 6 \\
\text { M.O protected }\end{array}$ & $\begin{array}{c}\text { Range } \\
\text { Mean } \pm \text { SD } \\
\text { p- value } \\
\text { p }^{\text {a }} \text {-value } \\
\mathbf{p}^{\text {b }} \text { - value }\end{array}$ & $\begin{array}{c}40.4-46.2 \\
43.05 \pm 2.4 \\
0.000 \\
0.000 \\
0.000\end{array}$ & $\begin{array}{c}1.9-2.55 \\
2.2 \pm 0.29 \\
0.000 \\
0.022 \\
0.000\end{array}$ \\
\hline $\begin{array}{c}\text { Group } 7 \\
\text { R.k protected }\end{array}$ & $\begin{array}{c}\text { Range } \\
\text { Mean } \pm \text { SD } \\
\text { p- value } \\
\text { p }^{\mathbf{a}} \text { - value } \\
\mathbf{p}^{\mathbf{c}} \text { - value }\end{array}$ & $\begin{array}{c}47.6-52 \\
48.6 \pm 1.67 \\
0.000 \\
0.000 \\
0.000\end{array}$ & $\begin{array}{c}1.88-2.5 \\
2.1 \pm 0.23 \\
0.000 \\
0.002 \\
0.000 \\
\end{array}$ \\
\hline $\begin{array}{c}\text { Group } 8 \\
\text { M.O+R.k protected }\end{array}$ & $\begin{array}{c}\text { Range } \\
\text { Mean } \pm \text { SD } \\
\text { p- value } \\
\text { p }^{\mathbf{a}-\text { value }} \\
\text { p }^{\text {d - value }}\end{array}$ & $\begin{array}{c}37.7-40.7 \\
38.9 \pm 0.98 \\
0.000 \\
0.000 \\
0.000\end{array}$ & $\begin{array}{c}1.9-2.3 \\
2.06 \pm 0.13 \\
0.000 \\
0.001 \\
0.000\end{array}$ \\
\hline $\begin{array}{c}\text { Group } 9 \\
\text { Treated M.O }\end{array}$ & $\begin{array}{c}\text { Range } \\
\text { Mean } \pm \text { SD } \\
\text { p- value } \\
\mathbf{p}^{\mathbf{a}} \text { - value } \\
\mathbf{p}^{\mathbf{b}} \text { - value }\end{array}$ & $\begin{array}{c}36.4-42 \\
39.2 \pm 1.86 \\
0.000 \\
0.000 \\
0.000\end{array}$ & $\begin{array}{c}1.5-2.3 \\
1.92 \pm 0.33 \\
0.000 \\
0.000 \\
0.000\end{array}$ \\
\hline $\begin{array}{l}\text { Group } 10 \\
\text { Treated R.k }\end{array}$ & $\begin{array}{c}\text { Range } \\
\text { Mean } \pm \text { SD } \\
\text { p- value } \\
\mathbf{p}^{\mathbf{a}} \text { - value } \\
\mathbf{p}^{\mathbf{c}} \text { - value } \\
\end{array}$ & $\begin{array}{c}34-43.2 \\
38.66 \pm 3.02 \\
0.000 \\
0.000 \\
0.000 \\
\end{array}$ & $\begin{array}{c}1.6-1.93 \\
1.7 \pm 0.12 \\
0.000 \\
0.000 \\
0.000 \\
\end{array}$ \\
\hline $\begin{array}{l}\text { Group } 11 \\
\text { Treated M.O +R.k }\end{array}$ & $\begin{array}{c}\text { Range } \\
\text { Mean } \pm \text { SD } \\
\text { p- value } \\
\text { p }^{\text {a }} \text {-value } \\
p^{\text {d }} \text { - value }\end{array}$ & $\begin{array}{c}30.4-41.3 \\
35.3 \pm 4.1 \\
0.000 \\
0.000 \\
0.000\end{array}$ & $\begin{array}{c}1.39-1.79 \\
1.59 \pm 0.14 \\
0.000 \\
0.000 \\
0.000\end{array}$ \\
\hline
\end{tabular}

$p$ value versus normal (negative control) $p^{(a)}$ value versus TAA (positive control). $p^{(\mathrm{c})}$ value versus R.K control. $p>0.05$ is non-significant, $p \leq 0.05$ is significant

$p^{(\mathrm{b})}$ value versus M.O control. $p^{(\mathrm{d})}$ value versus M.O+R.K control. 
Table 3: Stress related biomarkers in kidney tissue of different rat groups

\begin{tabular}{|c|c|c|c|c|}
\hline \multicolumn{2}{|c|}{ Group } & $\begin{array}{c}\text { Renal MDA } \\
(\mathrm{nmol} / \mathrm{g} . \text { tissue })\end{array}$ & $\begin{array}{r}\text { Renal NO } \\
(\mu \mathrm{mol} / \mathrm{L})\end{array}$ & $\begin{array}{c}\text { Renal PON } \\
(\mathrm{kU} / \mathrm{L})\end{array}$ \\
\hline $\begin{array}{l}\text { Group } 1 \\
\text { N. control }\end{array}$ & $\begin{array}{c}\text { Range } \\
\text { Mean } \pm \text { SD }\end{array}$ & $\begin{array}{c}22.3-31 \\
27 \pm 2.8\end{array}$ & $\begin{array}{c}12-23 \\
18 \pm 4\end{array}$ & $\begin{array}{l}36-54 \\
44 \pm 6.7\end{array}$ \\
\hline $\begin{array}{c}\text { Group } 2 \\
\text { M.O control }\end{array}$ & $\begin{array}{c}\text { Range } \\
\text { Mean } \pm \text { SD } \\
\text { p- value }\end{array}$ & $\begin{array}{c}21-33.2 \\
29 \pm 4.3 \\
0.451 \\
\end{array}$ & $\begin{array}{c}14-22 \\
18 \pm 2.7 \\
1.00\end{array}$ & $\begin{array}{c}39-46 \\
43 \pm 2.5 \\
0.699\end{array}$ \\
\hline $\begin{array}{l}\text { Group } 3 \\
\text { R.k control }\end{array}$ & $\begin{array}{c}\text { Range } \\
\text { Mean } \pm \text { SD } \\
\text { p- value }\end{array}$ & $\begin{array}{c}26-34 \\
30 \pm 3.4 \\
0.259\end{array}$ & $\begin{array}{c}16-23 \\
19 \pm 2.8 \\
0.644\end{array}$ & $\begin{array}{c}38-46 \\
42 \pm 3.15 \\
0.441\end{array}$ \\
\hline $\begin{array}{c}\text { Group } 4 \\
\text { M.O+R.k control }\end{array}$ & $\begin{array}{c}\text { Range } \\
\text { Mean } \pm \text { SD } \\
\text { p- value }\end{array}$ & $\begin{array}{c}21-31.2 \\
28 \pm 3.67 \\
0.705\end{array}$ & $\begin{array}{c}12-23 \\
18 \pm 3.35 \\
1.00\end{array}$ & $\begin{array}{c}36-46 \\
41 \pm 4.01 \\
0.249\end{array}$ \\
\hline $\begin{array}{c}\text { Group } 5 \\
\text { TAA control }\end{array}$ & $\begin{array}{c}\text { Range } \\
\text { Mean } \pm \text { SD } \\
\text { p- value }\end{array}$ & $\begin{array}{c}42-60 \\
53 \pm 6.4 \\
0.000\end{array}$ & $\begin{array}{c}23-36 \\
29 \pm 4.4 \\
0.000\end{array}$ & $\begin{array}{c}26-39 \\
31 \pm 4.6 \\
0.000\end{array}$ \\
\hline $\begin{array}{c}\text { Group } 6 \\
\text { M.O protected }\end{array}$ & $\begin{array}{c}\text { Range } \\
\text { Mean } \pm \text { SD } \\
\text { p- value } \\
\mathbf{p}^{\mathbf{a}-\text { value }} \\
\mathbf{p}^{\mathbf{b}} \text { - value }\end{array}$ & $\begin{array}{c}42-53 \\
47 \pm 3.8 \\
0.000 \\
0.027 \\
0.000\end{array}$ & $\begin{array}{c}19-34 \\
25 \pm 5.1 \\
0.002 \\
0.068 \\
0.002\end{array}$ & $\begin{array}{c}33-44 \\
39 \pm 3.56 \\
0.057 \\
0.003 \\
0.126\end{array}$ \\
\hline $\begin{array}{c}\text { Group } 7 \\
\text { R.k protected }\end{array}$ & $\begin{array}{c}\text { Range } \\
\text { Mean } \pm \text { SD } \\
\text { p- value } \\
\text { p }^{\text {a }} \text { - value } \\
\text { p }^{c} \text { - value }\end{array}$ & $\begin{array}{c}29-53 \\
45 \pm 8.3 \\
0.000 \\
0.004 \\
0.000\end{array}$ & $\begin{array}{c}22-26 \\
24 \pm 1.5 \\
0.007 \\
0.024 \\
0.024\end{array}$ & $\begin{array}{c}36-45 \\
40 \pm 3.5 \\
0.126 \\
0.001 \\
0.441\end{array}$ \\
\hline $\begin{array}{l}\text { Group } 8 \\
\text { M.O+R.k } \\
\text { protected }\end{array}$ & $\begin{array}{c}\text { Range } \\
\text { Mean } \pm \text { SD } \\
\text { p- value } \\
\text { p }^{\text {a }} \text { - value } \\
\text { p }^{\text {- }} \text {-value }\end{array}$ & $\begin{array}{c}38.4-45.3 \\
42.05 \pm 2.6 \\
0.000 \\
0.000 \\
0.000\end{array}$ & $\begin{array}{c}19-26 \\
23 \pm 2.9 \\
0.024 \\
0.007 \\
0.024\end{array}$ & $\begin{array}{c}30-46 \\
37 \pm 5.96 \\
0.009 \\
0.024 \\
0.126\end{array}$ \\
\hline $\begin{array}{c}\text { Group } 9 \\
\text { Treated M.O }\end{array}$ & $\begin{array}{c}\text { Range } \\
\text { Mean } \pm \text { SD } \\
\text { p- value } \\
\mathbf{p}^{\mathbf{a}}-\text { value } \\
\mathbf{p}^{\mathbf{b}}-\text { value }\end{array}$ & $\begin{array}{c}29-46 \\
40 \pm 6.2 \\
0.000 \\
0.000 \\
0.000\end{array}$ & $\begin{array}{c}17-26 \\
22.6 \pm 3.2 \\
0.034 \\
0.005 \\
0.034\end{array}$ & $\begin{array}{c}31-41 \\
36 \pm 3.2 \\
0.003 \\
0.057 \\
0.009\end{array}$ \\
\hline $\begin{array}{l}\text { Group } 10 \\
\text { Treated R.k }\end{array}$ & $\begin{array}{c}\text { Range } \\
\text { Mean } \pm \text { SD } \\
\text { p- value } \\
\mathbf{p}^{\mathbf{a}} \text { - value } \\
\mathbf{p}^{\mathbf{c}} \text { - value }\end{array}$ & $\begin{array}{c}40.4-46.2 \\
43.05 \pm 2.4 \\
0.000 \\
0.000 \\
0.000 \\
\end{array}$ & $\begin{array}{c}16-31 \\
25 \pm 5.4 \\
0.002 \\
0.068 \\
0.007 \\
\end{array}$ & $\begin{array}{c}27-44 \\
37 \pm 5.6 \\
0.009 \\
0.024 \\
0.057 \\
\end{array}$ \\
\hline $\begin{array}{l}\text { Group } 11 \\
\text { Treated M.O +R.k }\end{array}$ & $\begin{array}{c}\text { Range } \\
\text { Mean } \pm \text { SD } \\
\text { p- value } \\
\text { p }^{\text {a }- \text { value }} \\
\text { p }^{\text {- }- \text { value }}\end{array}$ & $\begin{array}{c}37.7-40.7 \\
38.9 \pm 0.9 \\
0.000 \\
0.000 \\
0.000\end{array}$ & $\begin{array}{c}18-28 \\
22 \pm 3.6 \\
0.068 \\
0.002 \\
0.068\end{array}$ & $\begin{array}{c}33-46 \\
39 \pm 4.3 \\
0.057 \\
0.003 \\
0.441\end{array}$ \\
\hline
\end{tabular}

$p$ value versus normal (negative control)

$p^{(\mathrm{a})}$ value versus TAA (positive control).

$p^{(\mathrm{c})}$ value versus R.K control.

$p^{(b)}$ value versus M.O control.

$p^{(\mathrm{d})}$ value versus M.O+R.K control.

$p>0.05$ is non-significant, $p \leq 0.05$ is significant 
Table 4: Stress related biomarkers in liver tissue of different rat groups

\begin{tabular}{|c|c|c|c|c|}
\hline \multicolumn{2}{|l|}{ Group } & $\begin{array}{r}\text { Hepatic MDA } \\
\text { (nmol/g. tissue) }\end{array}$ & $\begin{array}{c}\text { HepaticNO } \\
(\mu \mathrm{mol} / \mathrm{L})\end{array}$ & $\begin{array}{c}\text { Hepatic PON } \\
(\mathrm{kU} / \mathrm{L})\end{array}$ \\
\hline $\begin{array}{l}\text { Group } 1 \\
\text { N. control }\end{array}$ & $\begin{array}{c}\text { Range } \\
\text { Mean } \pm \text { SD }\end{array}$ & $\begin{array}{l}22-37 \\
28 \pm 4.8\end{array}$ & $\begin{array}{l}11-22 \\
15 \pm 4.3\end{array}$ & $\begin{array}{l}35-42 \\
38 \pm 2.5\end{array}$ \\
\hline $\begin{array}{c}\text { Group } 2 \\
\text { M.O control }\end{array}$ & $\begin{array}{c}\text { Range } \\
\text { Mean } \pm \text { SD } \\
\text { p- value }\end{array}$ & $\begin{array}{c}21-33 \\
29 \pm 4.27 \\
0.770\end{array}$ & $\begin{array}{c}10-29 \\
18 \pm 6.8 \\
0.297\end{array}$ & $\begin{array}{c}26.2-40.3 \\
33 \pm 5.5 \\
0.05\end{array}$ \\
\hline $\begin{array}{l}\text { Group } 3 \\
\text { R.k control }\end{array}$ & $\begin{array}{c}\text { Range } \\
\text { Mean } \pm \text { SD } \\
\text { p- value }\end{array}$ & $\begin{array}{c}26-34 \\
30 \pm 3.38 \\
0.559\end{array}$ & $\begin{array}{c}12-23 \\
17 \pm 4.15 \\
0.485\end{array}$ & $\begin{array}{c}28.3-46 \\
34 \pm 6.5 \\
0.123\end{array}$ \\
\hline $\begin{array}{c}\text { Group } 4 \\
\text { M.O+R.k control }\end{array}$ & $\begin{array}{c}\text { Range } \\
\text { Mean } \pm \text { SD } \\
\text { p- value }\end{array}$ & $\begin{array}{c}21-31 \\
28 \pm 3.67 \\
1.00\end{array}$ & $\begin{array}{c}12-23 \\
16 \pm 4.08 \\
0.727\end{array}$ & $\begin{array}{c}28-36 \\
32 \pm 3.1 \\
0.023\end{array}$ \\
\hline $\begin{array}{c}\text { Group } 5 \\
\text { TAA control }\end{array}$ & $\begin{array}{c}\text { Range } \\
\text { Mean } \pm \text { SD } \\
\text { p- value }\end{array}$ & $\begin{array}{c}30-61 \\
48 \pm 12.2 \\
0.000\end{array}$ & $\begin{array}{c}20-40 \\
30 \pm 6.9 \\
0.000\end{array}$ & $\begin{array}{c}18-29.3 \\
24 \pm 3.8 \\
0.000\end{array}$ \\
\hline $\begin{array}{c}\text { Group } 6 \\
\text { M.O protected }\end{array}$ & $\begin{array}{c}\text { Range } \\
\text { Mean } \pm \text { SD } \\
\text { p- value } \\
\text { p }^{\mathbf{a}} \text { - value } \\
\text { p }^{\mathbf{b}} \text { - value }\end{array}$ & $\begin{array}{c}24-53 \\
41 \pm 9.8 \\
0.000 \\
0.044 \\
0.001\end{array}$ & $\begin{array}{c}22-41 \\
29 \pm 7.1 \\
0.000 \\
0.727 \\
0.000\end{array}$ & $\begin{array}{c}21-31 \\
26 \pm 3.9 \\
0.000 \\
0.438 \\
0.008\end{array}$ \\
\hline $\begin{array}{c}\text { Group } 7 \\
\text { R.k protected }\end{array}$ & $\begin{array}{c}\text { Range } \\
\text { Mean } \pm \text { SD } \\
\text { p- value } \\
\mathbf{p}^{\mathbf{a}-\text { value }} \\
\mathbf{p}^{\mathbf{c}} \text { - value }\end{array}$ & $\begin{array}{c}38-45 \\
42.5 \pm 2.6 \\
0.000 \\
0.11 \\
0.001\end{array}$ & $\begin{array}{c}25-31 \\
28 \pm 2.26 \\
0.000 \\
0.485 \\
0.000\end{array}$ & $\begin{array}{c}21.2-31 \\
25 \pm 3.4 \\
0.000 \\
0.698 \\
0.001\end{array}$ \\
\hline $\begin{array}{c}\text { Group 8 } \\
\text { M.O+R.k protected }\end{array}$ & $\begin{array}{c}\text { Range } \\
\text { Mean } \pm \text { SD } \\
\text { p- value } \\
\mathbf{p}^{\mathbf{a}} \text { - value } \\
\mathbf{p}^{\mathbf{d}} \text { - value } \\
\end{array}$ & $\begin{array}{c}29-46 \\
40 \pm 6.2 \\
0.001 \\
0.022 \\
0.001 \\
\end{array}$ & $\begin{array}{c}21-32 \\
27 \pm 3.6 \\
0.000 \\
0.297 \\
0.000 \\
\end{array}$ & $\begin{array}{c}21-31.2 \\
28 \pm 3.67 \\
0.000 \\
0.124 \\
0.124 \\
\end{array}$ \\
\hline $\begin{array}{c}\text { Group } 9 \\
\text { Treated M.O }\end{array}$ & $\begin{array}{c}\text { Range } \\
\text { Mean } \pm \text { SD } \\
\text { p- value } \\
\text { p }^{\mathbf{a}} \text { - value } \\
\mathbf{p}^{\mathbf{b}} \text { - value }\end{array}$ & $\begin{array}{c}36-43 \\
39 \pm 2.6 \\
0.002 \\
0.11 \\
0.005\end{array}$ & $\begin{array}{c}20-30 \\
24 \pm 3.9 \\
0.003 \\
0.04 \\
0.04\end{array}$ & $\begin{array}{c}26-34 \\
30 \pm 3.4 \\
0.003 \\
0.023 \\
0.247\end{array}$ \\
\hline $\begin{array}{l}\text { Group } 10 \\
\text { Treated R.k }\end{array}$ & $\begin{array}{c}\text { Range } \\
\text { Mean } \pm \text { SD } \\
\text { p- value } \\
\mathbf{p}^{\mathbf{a}} \text { - value } \\
\mathbf{p}^{\mathbf{c}} \text { - value } \\
\end{array}$ & $\begin{array}{c}35-42 \\
38 \pm 2.6 \\
0.005 \\
0.05 \\
0.022 \\
\end{array}$ & $\begin{array}{c}20-26 \\
23 \pm 2.03 \\
0.007 \\
0.017 \\
0.04 \\
\end{array}$ & $\begin{array}{c}26-36 \\
31 \pm 4.2 \\
0.008 \\
0.008 \\
0.247 \\
\end{array}$ \\
\hline $\begin{array}{l}\text { Group } 11 \\
\text { Treated M.O +R.k }\end{array}$ & $\begin{array}{c}\text { Range } \\
\text { Mean } \pm \text { SD } \\
\text { p- value } \\
\text { p }^{\text {a }} \text { - value } \\
\text { p }^{\text {d }- \text { value }}\end{array}$ & $\begin{array}{c}\text { 31- } 40 \\
35 \pm 3.1 \\
0.044 \\
0.000 \\
0.044\end{array}$ & $\begin{array}{c}13-29 \\
22 \pm 5.7 \\
0.017 \\
0.007 \\
0.040\end{array}$ & $\begin{array}{c}26.2-43 \\
34 \pm 6.6 \\
0.123 \\
0.000 \\
0.438\end{array}$ \\
\hline
\end{tabular}

$p$ value versus normal (negative control)

$p^{(a)}$ value versus TAA (positive control).

$p^{(\mathrm{c})}$ value versus R.K control.

$p^{(\mathrm{b})}$ value versus M.O control.

$p>0.05$ is non-significant, $p \leq 0.05$ is significant

$p^{(\mathrm{d})}$ value versus M.O+R.K control. 


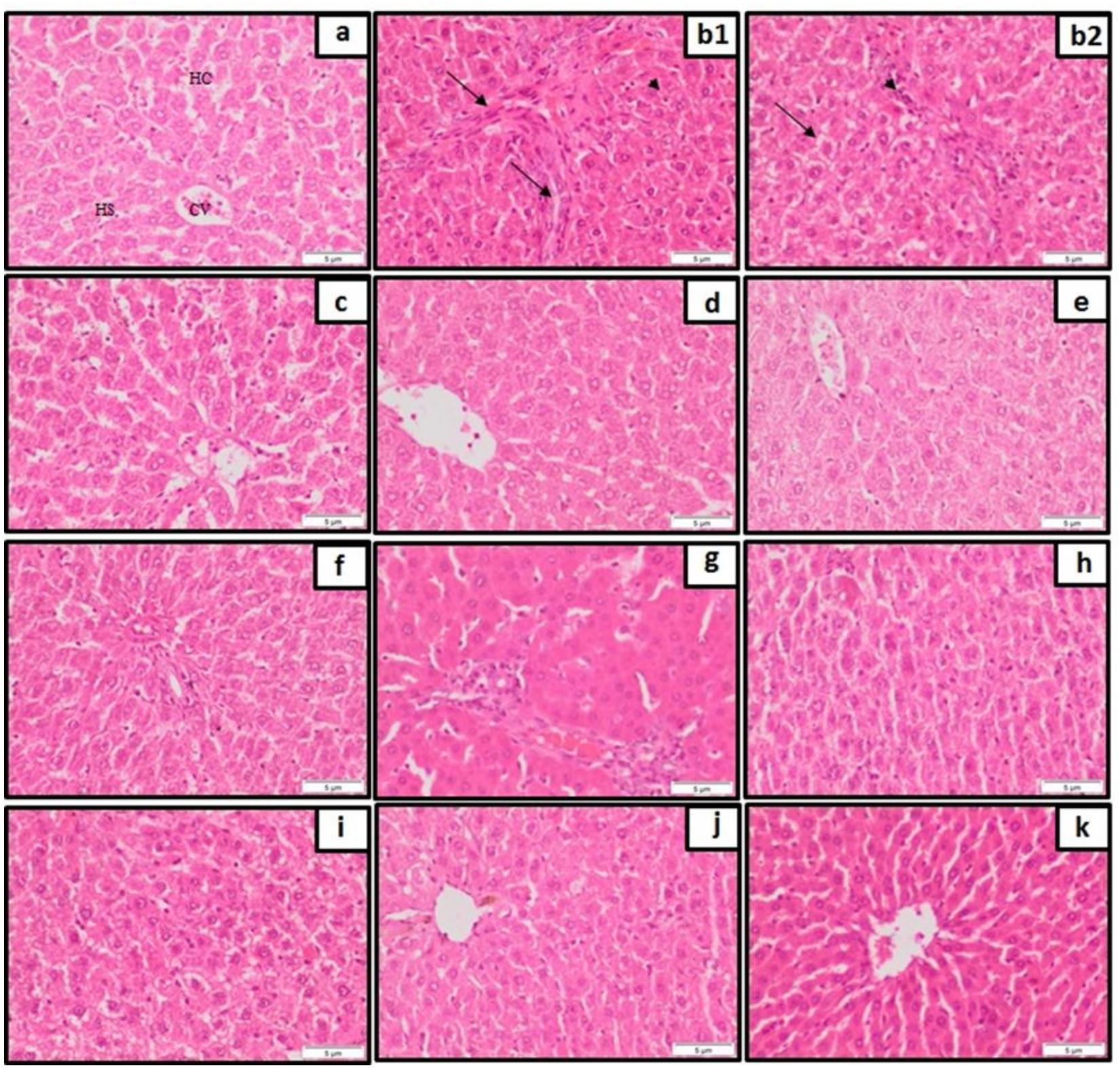

Fig.1. A photomicrograph of the liver of control rats (a) M.O control (c), R.K control (d) and M.O+ R.K control (e) groups showed normal hepatocyte histological structure. (b1,b2): Showed liver sections of TAA group degenerative changes in numerous hepatocytes, irregular dense fibrotic septa and focal necrosis. Protected M.O group (f) showed normal like architecture. Protected R.K group (g) showed congested portal tract associated with inflammatory infiltration. Protected M.O+R.K group (h) showed disturbance of the hepatic lobules. Treated rats given M.O, R.K and M.O+ R.K (i, j and $\mathrm{k}$ ) showed normal like architecture. 


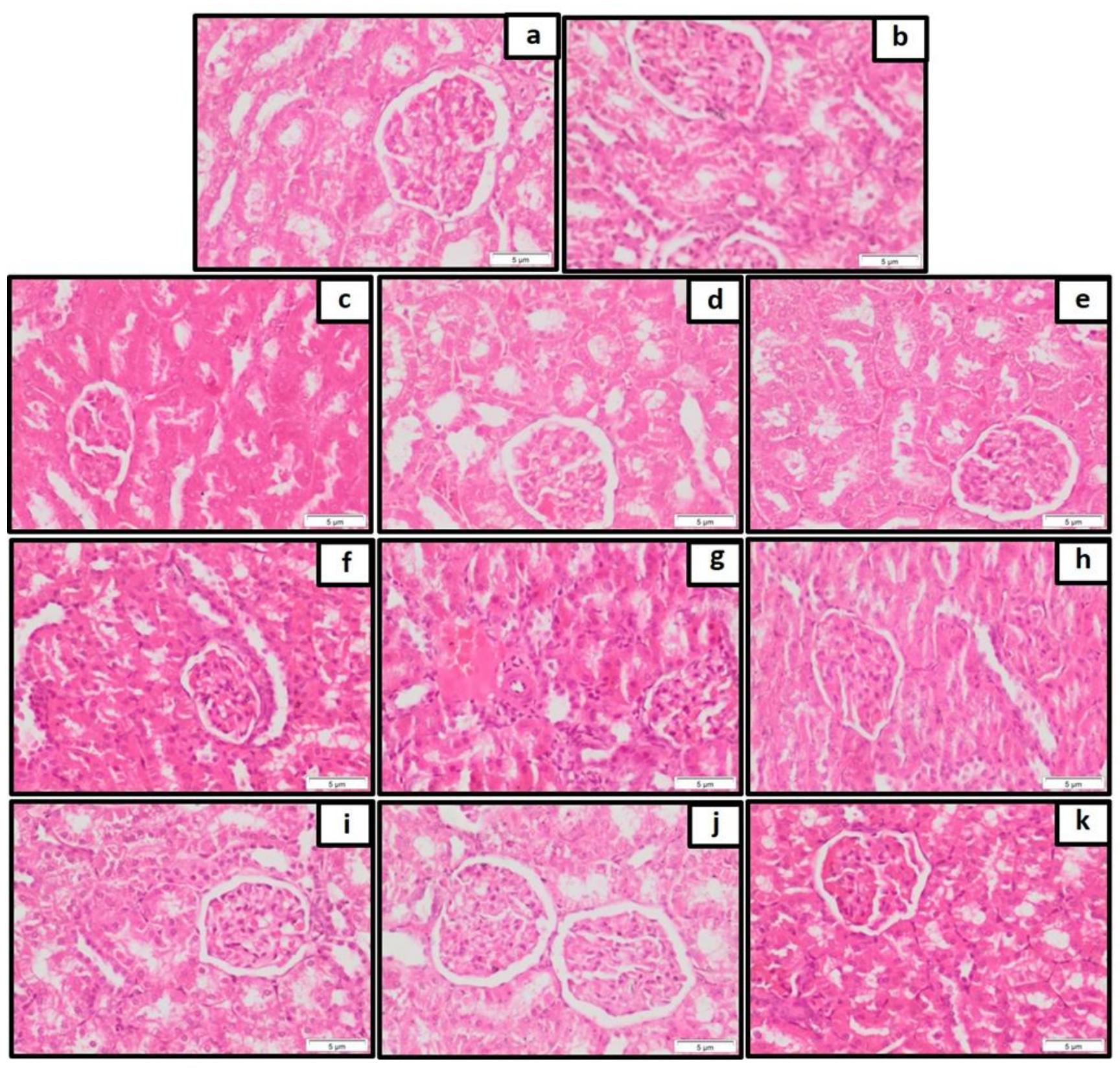

Fig.2. A photomicrograph of the kidney of control rats (a) M.O control (c), R.K control (d) and M.O+ R.K control (e) groups showed normal architecture of the renal corpuscles and renal tubules. (b): Showed kidney sections of TAA group cellular debris and haemorrhagic areas, glomeruli showed hypercellularity. Protected M.O group (f) showed normal like architecture. Protected R.K group (g) showed swelling of the renal corpuscles associated with wide urinary spaces, edema, and inflammatory infiltration. Protected M.O+R.K group (h) showed normal like architecture. Treated rats given M.O, R.K and M.O+ R.K (i, j and k) showed normal like architecture. 